\title{
Nyt boringsudstyr betaler sig - ny boringsservicevogn klarer det meste
}

Af hydrogeolog Johan Linderberg, Odense Vandselskab

Det kan være en kostelig og tidskrævende affære at udføre boringsundersøgelser. Med en ny boringsservicevogn kan Odense Vandselskab nu selv foretage omfattende undersøgelser på bare én arbejdsdag.

Odense Vandselskab leverer årligt ca. 10 mio. $\mathrm{m}^{3}$ vand til 154.000 forbrugere, der indvindes fra selskabets 45 boringer. En nyligt erhvervet boringsservicevogn betyder, at virksomheden nu selv kan foretage både simple og avancerede målinger i boringerne som led i virksomhedens løbende vedligeholdelse og vidensopbygning om grundvandsressourcerne.

Alsidigt måleudstyr i boringsservicevogn Materiellet er fysisk placeret i en containervogn, som trækkes af en terrængående Unimog forsynet med en stor kran. Udstyret i vognen bruges til at indhente data om de geologiske, hydrogeologiske og kemiske

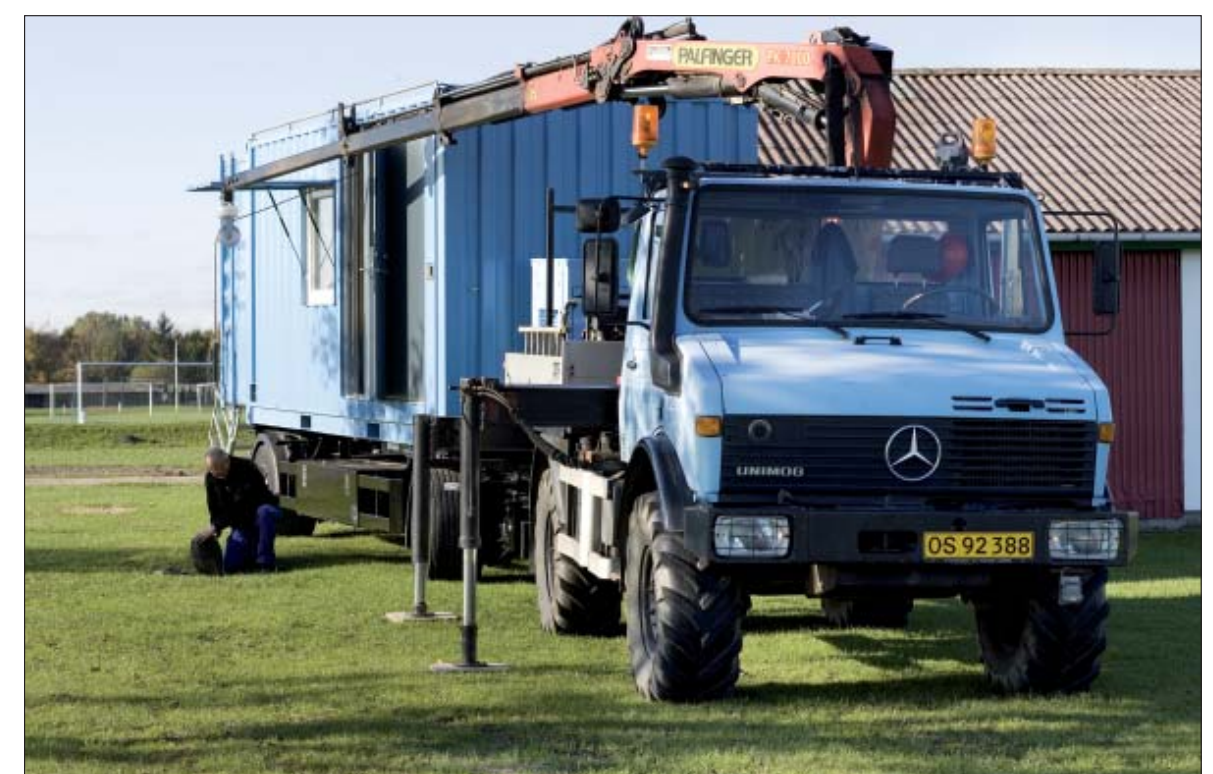

Odense Vandselskabs boringsservicevogn har ikke engang et år på bagen, men har allerede bidraget til udviklingen af nye metoder. Vognen og mandskab kan i øvrigt udlejes til interesserede ved henvendelse til Odense Vandselskab. (Foto: Mette Krull)

forhold i grundvandsmagasinet, boringens fysiske tilstand og udformning samt boringens - og dermed også magasinets - ydelse.

Den nye boringsservicevogn gør det både let og overskueligt at foretage målinger og inspektion - både før filtersætning og efter færdiggørelsen af boringer. Og virksomhedens nye udstyr er til stor nytte, når der eksempelvis skal indhentes standarddata $i$ forbindelse med rutineeftersyn.

De rutinemæssige kontroller, der inkluderer prøvepumpninger, prøveudtagninger, tryktest og svampeskylning af ledningsnet, tv-inspektion af boringshullet og geologging, sker som oftest på aktive produktionsboringer med installationer som dykpumper, kabler, stigerør og brønddæksler.

Den nye boringsservicevogn giver ud over de rutinemæssige kontroller og eftersynsopgaver også mulighed for at oparbejde selskabets boringer.

Omfattende undersøgelser på én dag Hvor Odense Vandselskab tidligere fik foretaget tv-inspektion og borehulslogging af både danske og udenlandske rådgivende

\section{Fra megger til loggingvogn og helikopter}

Odense Vandselskab har altid benyttet sig af de mest avancerede geoelektriske metoder. I 1954 købte Odense Vandforsynings visionære direktør, G.O. Andrup, en geofysisk megger i England med tilhørende trefod og generator, som blev brugt til kortlægning af grundvandsmagasiner. I 1990'erne vendte man blikket mod den danske forsker Kurt Sørensens metoder og introduce- rede el-logboringer og slæbegeoelektrik. Senest har Odense Vandselskab valgt at kombinere danske og britiske metoder. Virksomheden benytter i dag sin avancerede boringservicevogn med loggingudstyr, der er hentet hjem fra Wales, og drager nytte af Miljøcenter Odenses anvendelse af Kurt Sørensens SkyTEMmetode i arbejdet med kortlægning af grundvandsmagasiner. 


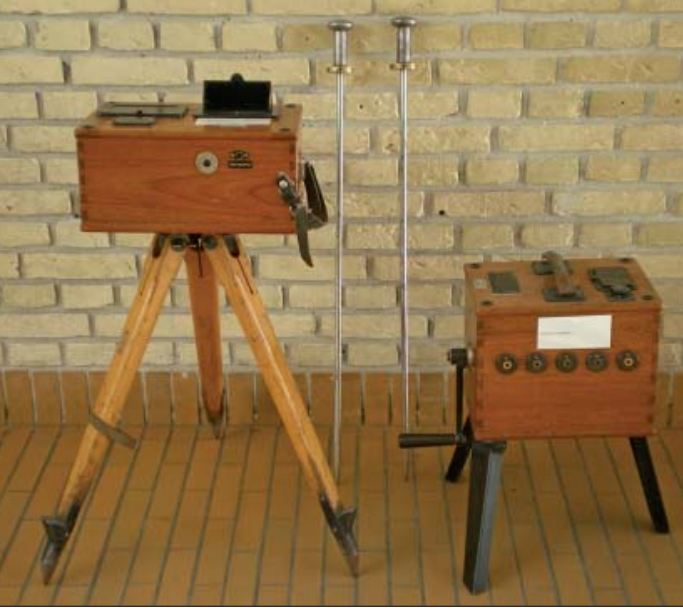

Apparatet til venstre er "The Geophysical Megger Earth Tester" fra Firmaet Evershed \& Vignoles Ltd. Apparatet til højre er en hånddreven DC-generator. Begge kan ses ved hovedindgangen på Geologisk Institut, Aarhus Universitet. (Foto: UVH)

ingeniørfirmaer, kan virksomheden i dag nøjes med sit eget udstyr og mandskab.

Som regel er der behov for rent visuelt at se, hvordan boringen ser ud ned gennem foringsrøret. Boringsservicevognens nye udstyr er vandtæt og udformet med et bevægeligt videokamera, som gør det muligt at danne sig et meget konkret overblik over boringens tilstand.

I boringer med lange filtre eller filtre, der spænder over flere magasiner, er det muligt hurtigt og effektivt at lokalisere de dele af filteret, som er problematiske med hensyn til vandkemien og vandgennemtrængningsevnen.

\section{Kort nyt}

\section{Oliemagt Brasilien}

De nye oliefund, som Brasilien har gjort, vurderes at sende landet op på en ottendeplads iblandt verdens olieproducerende lande. I $2007 \mathrm{blev}$ der fundet store olieforekomster ud for den brasilianske kyst. Med et forsigtigt skøn indeholder disse reserver ca. 30 milliarder tønder.

Brasilien har i mange år ført en energipolitik, der har baseret sig på biobrændsel. Spørgsmålet er nu, om det får Brasilien til at ændre kurs inden for energipolitikken. Hidindtil har Brasilien været at finde iblandt de skarpeste kritikere af USA, Kina og Indiens ukritiske forbrug af fossile brændstoffer, som menes at være en af årsagerne til den globale opvarmning.

$J P / S L J$

\section{Termografifotografering}

I Storbritannien er det nu i 20 byer muligt for borgerne at tjekke deres huses varmetab.
Det er muligt på en enkelt arbejdsdag at demontere, videoinspicere og reetablere boringen, forudsat at der ikke er forhold, som skal afhjælpes.

\section{Udvikling af nye metoder}

Selskabets nyerhvervelse har allerede ført til udviklingen af nyt udstyr baseret på den erfaring, som medarbejderne har opbygget ved hjælp af boringsservicevognen. Helt konkret drejer det sig om et unikt separationspumpeudstyr, der kan bruges til at udtage niveauspecifikke vandprøver i vilkårlig dybde fra 10-270 m under terræn. Derudover har Odense Vandselskab udviklet et pakkersystem, som kan isolere dele af filteret, samt et effektivt børstesystem til rensning af forerørets inderside og filterslidser.

Sidstnævnte foregår ved, at man injicerer en kemikalieblanding af fx syre eller hexametafosfat, som ved hjælp af trykluft fra boringsservicevognen presses ud i formationen gennem borehullets filterslidser. Med den indbyggede automatiske styring kan trykket bygges op og slækkes skiftevis, således at der opstår en udstrømmende og indstrømmende vandbevægelse, der "vasker" formationen ren for $\mathrm{fx}$ boremudder.

Dette har vist sig at være meget effektivt mod boremudder, som blokerer slidserne og ikke er blevet renset ud/mobiliseret ved den traditionelle renpumpning af en ny boring. Syretilsætning samt børstebearbejdning indvendigt i forerøret kan løsne belægninger og dermed øge boringernes ydeevne.
Den engelske virksomhed Hotmapping har specialiseret sig i fra luften at tage billeder af byer med en infrarød kamerateknologi. På firmaets hjemmeside kan borgerne finde deres hus og ved hjælp af en femtrins-farvekode se, om deres hus er ordentlig isoleret. Varmetabet vil fremgå af fotoet.

I Danmark arbejder Scankort på at videreudvikle teknologien fra Storbritannien, som kører med todimensionelle luftfotos. Målet er at udvikle termografiske luftfotografier i 3D. Med en sådan teknologi vil man ifølge Scankort kunne fastslå, om varmetabet i en bygning skyldes væggene, vinduerne eller taget.

I indeværende fyringssæson vil Scankort lave de første forsøg med varmefotografier. Den danske isoleringsproducent Rockwool, som har stor kommerciel interesse i, at forsøget bliver en succes, er også involveret $\mathrm{i}$ udviklingsarbejdet.

\section{Geologisk tidsskala}

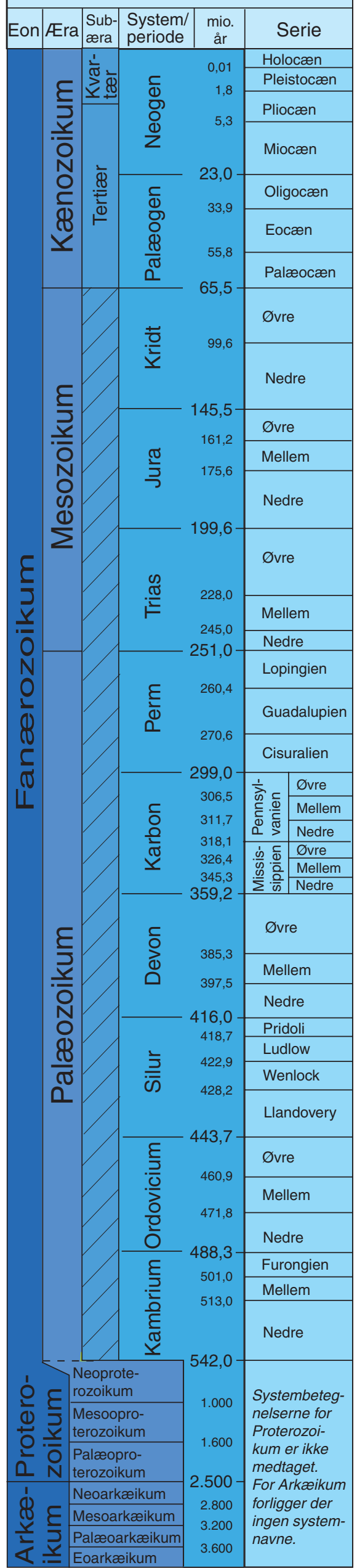

